\title{
Willingness to join community-based health insurance among rural households of Debub Bench District, Bench Maji Zone, Southwest Ethiopia
}

\author{
Melaku Haile ${ }^{1 *}$, Shimeles Ololo ${ }^{2}$ and Berhane Megersa ${ }^{3}$
}

\begin{abstract}
Background: Even though Ethiopia bears high burden of diseases, utilization of modern health care services is limited. One of the reasons for low utilization of healthcare services is the user-fee charges. Moving away from outof-pocket charges for healthcare at the time of use is an important step towards averting the financial hardship associated with paying for health service. Prepaid plans for health are not accustomed in Ethiopia. Therefore, social and community based health insurance schemes were introduced since 2010.

In this study, willingness of rural households in Debub Bench District, to join community based health insurance was assessed.
\end{abstract}

Method: Cross-sectional community based study was conducted in Debub Bench District in March 2013 using a pretested structured questionnaire. Two stage sampling technique was used to select 845 households as study units which were allocated to the kebeles proportionately. The sampled households were selected using simple random sampling technique. Data were entered into EPIDATA 3.0 and analyzed with SPSS version 20.

Result: Among 845 sampled households, 808 were interviewed (95.6\% response rate). About 78\% of the respondents were willing to join the scheme. Most of demographic, socioeconomic variables and social capital were found to be significantly associated with willingness to join community based health insurance.

Conclusion: If the scheme is initiated in the district, majority of the households will enroll in the community based health insurance. Farmers, the married households, Bench ethnic groups and illiterate, the dominant segments of the population, are more likely to enroll the schemes. Therefore initiation of the scheme is beneficial in the district.

Keywords: Community based health insurance, Willingness to join, Rural households, Southwest Ethiopia

\section{Background}

In terms of access to modern health care and various other health indicators, Ethiopia ranks low even as compared to other low- income countries [1]. The country bears a high burden of disease mainly due to preventable diseases and conditions. For example, in 2011 all the top leading causes of mortality were easily preventable diseases such as malaria, pneumonia and respiratory tract diseases [2]. In spite of high burden, utilization of modern health care services is limited [3]. One of the reasons

\footnotetext{
* Correspondence: mhaile67@ýahoo.com

${ }^{1}$ Aman College of Health Sciences, Southern Nations, Nationalities and People's Regional Health Bureau, P.O. Box 240, Mizan-Aman, Ethiopia Full list of author information is available at the end of the article
}

for low utilization of healthcare services is the user-fee charges [4].

In Ethiopia, 38.5\% of the total health expenditure was covered through out-of-pocket charges, which is higher than that of other African countries, which was $30.6 \%$ in 2008 [3,5]. Nevertheless, Ethiopia's per capita public spending for health (14 US\$ in 2008) remains far below even that of other African and low income countries (83 US\$ and 32 US\$ respectively in 2008) [5].

Health care expenses were devastating and had long term effects on economic situations to the majority of households in Ethiopia. Consequently, it was suggested that alternative mechanisms such as health taxes should be established to cover health care expenses [6]. Moving away from out-of pocket charges for healthcare at the 
time of use is an important step towards averting the financial hardship associated with paying for health service [7]. But, in 2008 prepaid plans covered only $1.5 \%$ of the total private expenditure on health in Ethiopia [5].

To increase the prepaid plan coverage and access to modern health care services, Ethiopian government has developed health insurances strategy. Two types of health insurance schemes were introduced in Ethiopia since 2010. The first kind the schemes is social health insurance (SHI). Social health insurance is in implementation phase and intended to cover $10.46 \%$ of the population who are engaged in formal sectors. In Ethiopia, enrolling in SHI is compulsory for all in the formal sectors. This kind of health insurance scheme is expected to be fully implemented in the mid-of 2014.

The other health insurance scheme is communitybased health insurance ( $\mathrm{CBHI}$ ), which is being piloted in 13 selected districts in Ethiopia and intended to cover $83.6 \%$ of the population of Ethiopia who are engaged in informal sectors; mainly those dwellers of rural areas [8]. The CBHIS has not been rolled out anywhere in the nation so far. It is expected to roll out after in 2015 or beyond throughout all districts in Ethiopia.

Unlike the SHI scheme, joining CBHI is based on voluntary decision of the households. In the pilot districts, households which join the community-based health insurance are expected to pay 180 Ethiopian Birr (10.4 US\$) annually as a premium. However, the members' contribution varies among the pilot districts ranging from 34.4 ETB-132 ETB [9].

Community based health insurance (CBHI) covers a wide variety of health insurance arrangements - with vast gradients in terms of ownership, management, membership, and service as well as financial coverage - in distinctive settings and designed for different population groups [10]. It is characterized by community-based social dynamics \& risk pooling, solidarity, participatory decision-making \& management, non-profitability \& voluntary affiliation [11].

The benefits packages of CBHI in Ethiopia include all family health services and curative care that are part of the essential health package in Ethiopia when the scheme is scaled up to full implementation. Curative services include inpatient, outpatient services and acute illnesses [12].

Before establishing community-based health insurance scheme (CBHIS), its feasibility (i.e., its acceptance within the community and its sustainability) should be determined. Sustainability is determined by the design of the scheme, while acceptability must be tested in community surveys or in pilots through assessment of the people's willingness to join (WTJ) \& willingness to pay (WTP) before fully implementing CBHI [13].

In general demand studies are rarely collected or used as part of designing health insurance schemes in developing countries [14]. As a result, enrollments are low in many places where CBHI are established. For example a review of CBHIS found that $50 \%$ of them had less than 500 members while only $2 \%$ of the schemes had more than large number of enrollees $(100,000$ members) [15].

In Ethiopia, $76.4 \%$ people wanted to enroll in iddir based health insurance scheme by paying 7.60 Ethiopian Birr (ETB) monthly per household in 2007. In this study, monthly income, educational status and relation of respondent to household, participation in iddirs had statistically significant effect on willingness to pay for IBHIS [16]. Iddirs are funeral associations in Ethiopia that ensure a pay-out in cash and in kind at the time of a funeral for a deceased member of the family of a member of the group [17].

Another study elicited the community's willingness to join and pay for a hypothetical community based health insurance scheme in rural Ethiopia using double bounded dichotomous choice contingent valuation method revealed that $60 \%$ of the rural people in Ethiopia were willing to join potential CBHI by paying 4.75 ETB (approximately, 0.60 US\$) as monthly premium [18]. The study elicited the households WTJ and WTP for community-based insurance schemes by presenting community based health insurance scenario.

In the current study area, there are no any published data on demand of CBHI. Hence nothing is known about the level of acceptance of the CBHIS which is to be implemented nationally after two years. The investigators were initiated to conduct this study to fill this gap by assessing the WTJ the CBHIS in the specified area as it identifies the demand of the households for CBHI in the area. It is believed that this study will help policy makers to address factors which affect the households' WTJ make the benefit of the planned community-based health insurance scheme.

The objective of this study was to assess willingness to join community-based health insurance scheme and factors associated with it among rural households in Debub Bench District of Bench Maji Zone, South-west Ethiopia, 2013.

\section{Methods}

A community based cross-sectional study was conducted in rural kebeles of Debub Bench District, Bench Maji Zone; Southwest Ethiopia in March 2013. The district is one of the 9 districts in Bench Maji Zone of Southern Nations, Nationalities and People's Region (SNNPR). The district is located $858 \mathrm{kms}$ south west of Hawassa, the capital of SNNPR, and $588 \mathrm{kms}$ south west of Addis Ababa, the capital of Ethiopia. There are 25 rural kebeles and 1 town administration in the district. The population of the district was projected to be 127,477 in 2012 
[19]. ("Kebele" is the lowest administrative body in Ethiopia which comprises at least 1000 households or population of 5000 people).

A sample size of 845 was calculated by a single proportion formula, taking $\mathrm{P}=50 \%$ (expected rate of willingness to join community based health insurance scheme), considering a design effect of 2 and an anticipated non-response rate of $10 \%$.

A two-stage sampling technique was used to select participating households. The primary sampling units were kebeles. From 25 rural kebeles, 8 were selected randomly. The participating households were allocated to these 8 kebeles proportionate to the sizes of the kebeles and selected using simple random sampling technique (Figure 1).

The identity numbers of the houses, issued to each house in the kebeles by the administration of the district, were used to develop sampling frames of the households. Residents whose age were 18 years and above and who lived for more than six months in the kebeles were eligible for the study. Households with heads or spouses employed in formal sectors were excluded from the study because, according to the health insurance proclamation of Ethiopia, such households are covered by the social health insurance scheme which is in to be rolled out in the middle of 2014.

A pre-tested structured questionnaire was used. The questionnaire comprised of variables on demographic and socioeconomic characteristics, health status and health care and health related variables, social capital, participation in iddirs, willingness to participate in community based health insurance schemes and debriefing questions.

Before the respondent was asked his/her WTJ, community based health insurance scenario which was adapted from a willingness-to-pay study for CHI in Burkina Faso [20] and modified based on the benefit packages of Ethiopian community based insurance, was presented in details.

Presenting the scenario was important in this study since the respondents have little or no idea about community-based health insurance schemes. The scenario discloses the benefit packages of the scheme, membership payments and other issues about the CBHIS of Ethiopia (Additional file 1).

Data were collected by eight first cycle government school teachers. Two health professionals were recruited as field supervisors. Training was provided to both the data collectors and supervisors for two days and one day respectively. To reduce biases, the data collectors clearly told the respondents that they have no any link with the proposed CBHI.

Data were edited, cleaned, coded and entered in to Epidata 3.0, validated in double entry validation and exported to SPSS version 20.

The statistical analysis comprised three sequential steps. First, the associations between potential predictors of WTJ were assessed using contingency table analyses. The $\mathrm{x}^{2}$ statistic and its corresponding odds ratio, and 95\% confidence intervals were computed to assess the significance and magnitude of these bivariate associations. To avoid unstable estimates, the cut-off point of

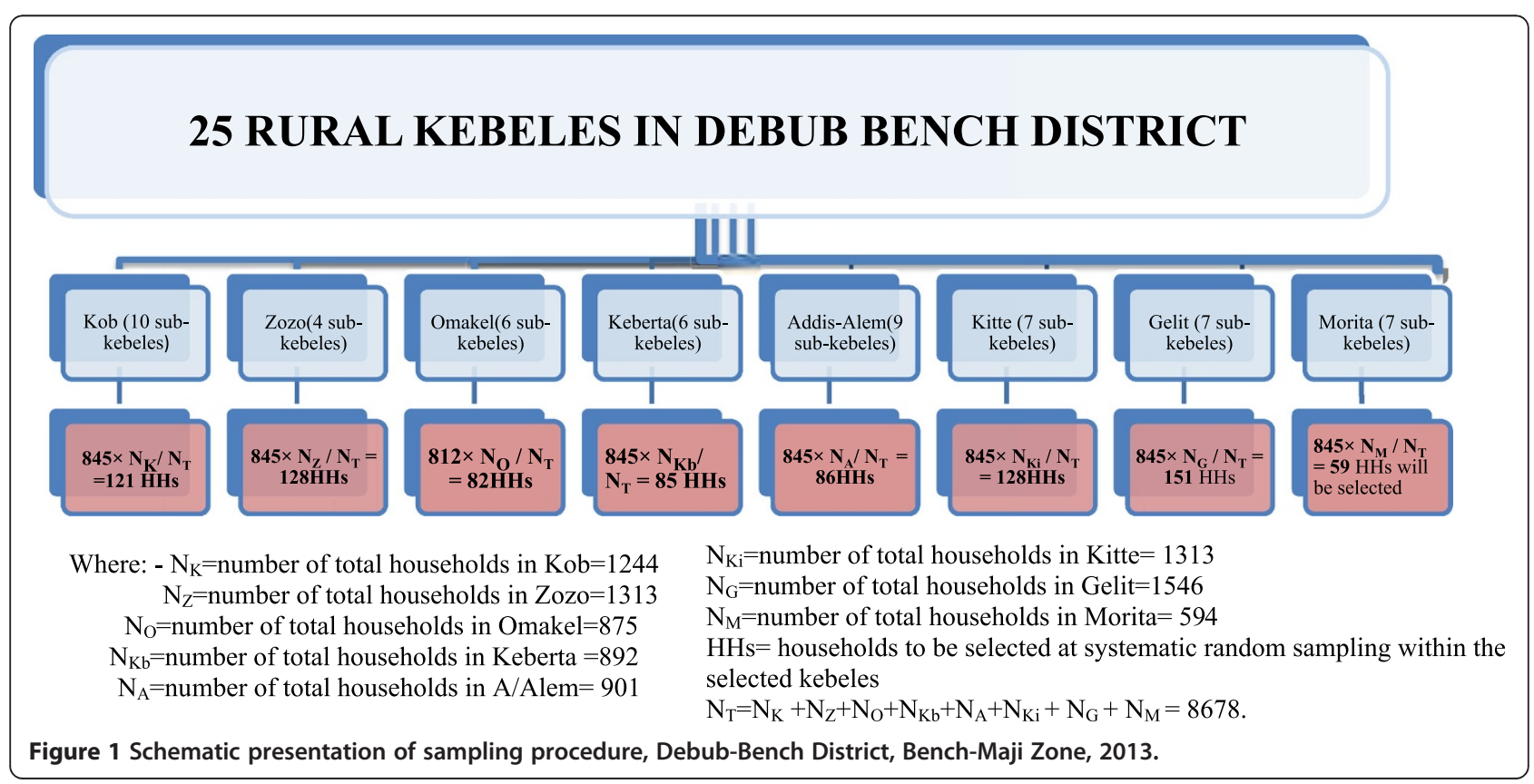


0.20 was used in the bivariate analysis to select variables for fitting a multivariate logistic regression model and identify the independent contribution of each variable while adjusting for the effects of other variables in the model.

The $\mathrm{x}^{2}$ statistic tests the overall statistical significance of the model, and adjusted odds ratios and their corresponding 95\% confidence intervals were reported to assess the association between individual variables and willingness to join CBHI. Finally, it was evaluated that variables identified as associated $(\mathrm{P}<0.05)$ with willingness to join the $\mathrm{CBHI}$ in the multivariate logistic regressing analysis were used to predict WTJ.

Ethical clearance was obtained from Ethical Review Committee of College of Public Health and Medical Sciences of Jimma University. Support letters were obtained from Debub Bench District Administration, education and health offices. Permission was sought from the Kebeles administration before conducting the study. Verbal consent was obtained from the respondents.

\section{Results and discussion \\ Result}

Of 845 sampled households, 808 participated in the study which yielded a response rate of $95.6 \%$. The median age of respondents was 32, ranging 18-87 years. Among them, 574 (71\%) were male, 550 (68.1\%) Protestant Christians, 519 (64.2\%) Bench ethnic groups, 675 (83.5\%) married (574 monogamous/monandrous and 101 polygamous), 615 (76.1\%) farmers, 388 (48\%) were illiterate and 654 (80.9\%) were head of the household. The median number of the household members was 5 with range of 1-13. The median annual household income, as estimated from the amount earned from sales of coffee, khat, maize cassava and other local products such as fruits, honey dairy products, etc., in one year time, was 2475 ETB (143 USD), ranging between 100-18,600 ETB (5.8-1075.1 USD). From the analysis of the wealth index, $31.6 \%$ of the households were found in the second and $24.0 \%$ in the highest wealth quintiles (Table 1).

Seven hundred and forty seven (92.5\%) of the households were participating in iddirs. Out of them 635 (85 were participating in one iddir) and the remaining 112 households in more than one iddirs. The median contribution of the households to iddirs was 1 ETB per month with range of 1-4 ETB.

Regarding individual level social capital, 233 (28.8\%), $545(56.4 \%)$ and 119 (14.7\%) of the households were of low (lower than the 25th percentile), middle (between 25th and 75th percentiles) and high (above 75th percentiles of horizontal trust index) individual level horizontal trust respectively. Also, 222 (27.5\%), 451 (55.8\%) and 135 (16.7\%) of the households were of low, middle and high individual level reciprocity respectively.
Table 1 Demographic and socioeconomic characteristics of the study participants in Debub Bench District, Southwest Ethiopia, $2013(n=808)$

\begin{tabular}{|c|c|c|}
\hline Description & & Frequency (\%) \\
\hline \multirow[t]{2}{*}{ Sex of the respondent } & Female & $234(29.0)$ \\
\hline & Male & $574(71.0)$ \\
\hline \multirow[t]{3}{*}{ Relationship } & Head & $654(80.9)$ \\
\hline & Spouse & $132(16.3)$ \\
\hline & Others (Child, parent) & $22(2.7)$ \\
\hline \multirow{4}{*}{$\begin{array}{l}\text { Religion of the } \\
\text { respondent }\end{array}$} & Protestant & $550(68.1)$ \\
\hline & Orthodox & 199 (24.6) \\
\hline & Muslim & $41(5.1)$ \\
\hline & Others & $18(2.2)$ \\
\hline \multirow{5}{*}{$\begin{array}{l}\text { Marital status of the } \\
\text { respondent }\end{array}$} & Monogamous/monandrous & $573(70.9)$ \\
\hline & Polygamous/polyandrous & $101(12.5)$ \\
\hline & Single & $55(6.8)$ \\
\hline & Widowed & $24(3.0)$ \\
\hline & Divorced & $55(6.8)$ \\
\hline \multirow{5}{*}{$\begin{array}{l}\text { Occupation of the } \\
\text { respondent }\end{array}$} & Farmer & $615(76.1)$ \\
\hline & Housewife & $113(14.0)$ \\
\hline & Merchant & $36(4.5)$ \\
\hline & Student & $30(3.7)$ \\
\hline & Others & $14(1.7)$ \\
\hline \multirow{4}{*}{$\begin{array}{l}\text { Ethnicity of the } \\
\text { respondent }\end{array}$} & Bench & $519(64.2)$ \\
\hline & Amhara & $116(14.4)$ \\
\hline & Kaffa & $64(7.9)$ \\
\hline & Others & 109 (13.5) \\
\hline \multirow{4}{*}{$\begin{array}{l}\text { Educational status } \\
\text { of the respondent }\end{array}$} & Illiterate & $388(48.0)$ \\
\hline & Read and write & $221(27.4)$ \\
\hline & Grade 1-8 & $178(22.0)$ \\
\hline & $>=$ Secondary school & $21(2.6)$ \\
\hline \multirow{5}{*}{$\begin{array}{l}\text { Wealth quintile of } \\
\text { the household }\end{array}$} & Lowest wealth quintile & $70(8.7)$ \\
\hline & Second wealth quintile & $255(31.6)$ \\
\hline & Middle wealth quintile & $164(20.3)$ \\
\hline & Fourth wealth quintile & $125(15.5)$ \\
\hline & Highest wealth quintile & $194(24.0)$ \\
\hline \multirow{3}{*}{$\begin{array}{l}\text { Category of annual } \\
\text { income }\end{array}$} & Lower than 1100 birr & $198(24.5)$ \\
\hline & 1100-4300 birr & 409 (50.6) \\
\hline & More than 4300 birr & $201(24.9)$ \\
\hline
\end{tabular}

With respect to health status and health related variables, 50 (6.2\%) of the respondents evaluated their family's health status to be very poor and 98 (12.1\%) very high. Sixty one $(7.5 \%)$ of the participants had at least one member with chronic disease or disability; and 250 (30.9\%) of the households had at least one member who had encountered illnesses 3 months prior to data collection. Among the ill 231 (92.4\%) had sought treatment 
for the illnesses they experienced, and 219 (94.8\%) got treatment. The remaining 12 did not get treatment because, mainly, lack of money (Table 2).

Of 219 who got treatment, $41.1 \%$ preferred to go to private clinics. They preferred the specified institutions because of its physical accessibility (47.5\%), effective service $(30.1 \%)$, not too crowded $(8.7 \%)$, not expensive services $(8.2 \%)$, or other reasons (5.5\%) (Table 2 ).

The median expenditure of the 219 households which sought treatments was $170 \mathrm{ETB}$ with range of 18 to 2000 ETB. Two hundred and four (93.2\%) of the households covered the medical expenses by themselves. One hundred and eighty seven (85.4\%) of these households reported that it was (very) difficult to cover payments for treatments. As a result, 68 (36.4\%) of them were assisted by relatives to cover the medical costs; 38 (20.3\%) drew from their savings, and 27 (14.4\%) borrowed from someone. The remaining had to sell capital assets such as cows (17.6\%), cut back on other things, food, drink, cloth etc. (9.1\%), undertook extra works and search for other means $(2.2 \%)$ to cover the payments for treatment (Table 2).

Of 808 respondents, 278 (34.4\%) reported that they had borrowed money for covering health care expenses within one year before the data were collected. The median amount that these households borrowed was 200 ETB (11.6 USD), ranging 30-2000 ETB (1.7-115.6 USD) (Table 2).

Regarding the distance of home of the household to the nearby health facility (private clinics, health centre or public hospital), it was reported that the median time it takes to reach the nearby health facility was 50 minutes, range between 3 minutes to 180 minutes (Table 2).

Among the participants, 629 (77.8\%) were willing to join the proposed community based health insurance. Four hundred and seventy five $(75.5 \%)$ of the respondents wanted to join the scheme to get free access to health care. And, 59 (33\%) of 179 respondents did not want to join the scheme because they do not need health insurance (Table 3).

The study revealed that a number of variables affect the households' decision in willingness to join the proposed community based health insurance scheme. In multivariate analyses, most of the demographic variables (age, relationship of the respondent to the household head, marital status, occupation and ethnicity of the respondent, as well as the household's family size) were significantly associated with WTJ the CBHIS.

Age had negative associations with the probability of WTJ the CBHIS. The younger were $6 \%$ more likely to join the scheme than the older (95\% CI of AOR: .914, .974). Spouses were $59 \%$ less likely to join the scheme, in comparison with heads of the households (95\% CI of AOR: $.174, .967)$. In comparison to monogamous/monandrous, the single were $87.7 \%$ less likely to join the scheme (95\% CI of AOR: .032, .474). Occupationally, housewives were more likely to join the scheme than farmers (AOR= 11.917; 95\% CI AOR: [4.017, 35.357]). Ethnically, households which belong to Kaffa ethnicity were $81.6 \%$ less likely to join the scheme than Bench $(95 \%$ CI of AOR: .072, .468). Size of the family was positively associated with WTJ decisions of the households. As the number of the household members increase, the probability of WTJ increased by $69 \%$ (95\% CI AOR: 1.363, 2.099) (Table 4).

Socioeconomic statuses of the respondents (educational status, wealth index and annual incomes) had also statistically significant associations with the households' decision in WTJ the CBHIS. Respondents who had no education were about 3 times more likely to join the scheme than those who completed grade $1-8$ (95\% CI of AOR: 1.355, 7.143). Households who were in the highest wealth quintile were more than 4 times more likely to join the scheme than those who were in the second wealth quintile (95\% CI of AOR: 1.626, 10.931). in the same manner, households with annual income 11004300 birrs were 2.105 times more likely to join the scheme than whose income was less than 4300 birrs [95\% CI of AOR: 1.215, 3.650] (Table 4).

Participation in iddirs, number of iddirs the households participate in and amount of money the households contribute for iddir were not statistically significant in multivariate analyses. But the variables which measure both individual level and community level social capitals were positively associated with WTJ the CBHIS. Households with low individual level horizontal trust level were 93.6\% less likely to join CBHIS than middle level ones (95\% CI of AOR: .025, .165). Households of high individual level reciprocity were about 5 times more likely to join the scheme than those in middle level (95\% CI AOR: 1.362, 18.052). Community level horizontal trust was strong positive predictor for WTJ community based health insurance $(\mathrm{AOR}=25.2$, 95\% CI AOR: 6.355, 100.195). But community level reciprocity had no association in the decision of the household to join CBHIS (Table 4).

In case of health related variables, only self-reported health status of the household, borrowing money for covering treatments, and distance of the house to nearby health care facility were found to be significant predictors for the households' WTJ decisions. Self-reported health status had negative association with the households' WTJ. Borrowing money for health care payment was positively associated with WTJ. Households which borrowed money were about 3 times more likely to join the scheme than those who did not borrow (95\% CI of AOR: $1.403,5.730)$. Distance of the health facility to the home of the household, as measured by time taken to arrive at the nearby HF (HFs, here refer to hospital, public health center or private clinics), was negatively 
Table 2 Health and health related situations in Debub Bench District, Southwest Ethiopia, 2013

\begin{tabular}{|c|c|c|c|c|c|}
\hline \multicolumn{2}{|l|}{ Descriptions } & \multirow{2}{*}{$\frac{\text { Freq (\%) }}{50(6.2)}$} & \multirow{6}{*}{$\begin{array}{l}\text { Means of getting money } \\
\text { for health care payment } \\
(n=187)\end{array}$} & \multirow{2}{*}{$\begin{array}{l}\text { Borrow from someon } \\
\text { Assisted by relatives }\end{array}$} & \multirow{2}{*}{$\begin{array}{l}27(14.4) \\
68(36.4)\end{array}$} \\
\hline \multirow{5}{*}{$\begin{array}{l}\text { Self-reported health status of } \\
\text { the household }(n=808)\end{array}$} & Very poor & & & & \\
\hline & Poor & $166(20.5)$ & & Undertaken extra work & $2(1.1)$ \\
\hline & Medium & $270(33.4)$ & & \multirow{2}{*}{$\begin{array}{l}\text { Sell capital assets such } \\
\text { as cows }\end{array}$} & \multirow[t]{2}{*}{$33(17.6)$} \\
\hline & High & $224(27.7)$ & & & \\
\hline & Very high & $98(12.1)$ & & \multirow{2}{*}{$\begin{array}{l}\text { Cut back on other } \\
\text { things, food, etc. }\end{array}$} & $19(10.2)$ \\
\hline \multirow{3}{*}{$\begin{array}{l}\text { Persons with chronic illness } \\
\text { and/or disability in the } \\
\text { household ( } n=808)\end{array}$} & No & $747(92.5)$ & \multirow{3}{*}{$\begin{array}{l}\text { Borrow money for medical } \\
\text { costs within last year } \\
(n=808)\end{array}$} & & \multirow[b]{2}{*}{$530(65.6)$} \\
\hline & Yes & $61(75)$ & & No & \\
\hline & & & & Yes & $278(34.4)$ \\
\hline \multirow{2}{*}{$\begin{array}{l}\text { Any illness encountered during } \\
\text { the past } 3 \text { mths }(n=808)\end{array}$} & No & $558(69.1)$ & \multirow{4}{*}{$\begin{array}{l}\text { The nearest conventional } \\
\text { health institution to the } \\
\text { respondents' home }(n=808)\end{array}$} & Health center & \multirow{2}{*}{$\begin{array}{l}373(46.2) \\
367(45.4)\end{array}$} \\
\hline & Yes & $250(30.9)$ & & Clinic (Private) & \\
\hline \multirow{2}{*}{$\begin{array}{l}\text { Seek of medical treatment for } \\
\text { the recent episode }(n=250)\end{array}$} & No & $19(7.6)$ & & & \multirow{2}{*}{$68(8.4)$} \\
\hline & Yes & $231(92.4)$ & & & \\
\hline \multirow[t]{2}{*}{ Get treatment $(n=231)$} & No & $12(5.2)$ & \multirow{4}{*}{\multicolumn{3}{|c|}{$\begin{array}{l}\text { associated with WTJ. The probability of joining the } \\
\text { scheme decreases by } 1.6 \% \text { as the time taken to reach the } \\
\text { HFs increases by one minute. ( } 95 \% \text { CI of AOR: } .973 \text {, } \\
.992 \text { ) (Table 4). }\end{array}$}} \\
\hline & Yes & $219(94.8)$ & & & \\
\hline Place of treatment $(n=219)$ & Private Heath Facility & $90(41.1)$ & & & \\
\hline & Public health center & $65(29.7)$ & & & \\
\hline & Public hospital & $49(22.4)$ & & & \\
\hline & $\begin{array}{l}\text { Other (self-treatment, } \\
\text { traditional healer and } \\
\text { local drug vendor) }\end{array}$ & $15(6.8)$ & $\begin{array}{l}\text { Discussion } \\
\text { After presenting the sce } \\
\text { insurance scheme, the }\end{array}$ & $\begin{array}{l}\text { lario of commun } \\
\text { espondents were }\end{array}$ & $\begin{array}{l}\text { based health } \\
\text { sked whether }\end{array}$ \\
\hline $\begin{array}{l}\text { Reasons for going } \\
\text { there }(n=219)\end{array}$ & $\begin{array}{l}\text { The HF was physically } \\
\text { accessible }\end{array}$ & $104(47.5)$ & $\begin{array}{l}\text { they were willing to joi } \\
\text { ios simplifies underst }\end{array}$ & $\begin{array}{l}\text { the scheme. Pre } \\
\text { ading of hypotl }\end{array}$ & $\begin{array}{l}\text { nting scenar- } \\
\text { ical markets }\end{array}$ \\
\hline & The HF was not expensive & $18(8.2)$ & such as community- & ased health insu & nce schemes \\
\hline & $\begin{array}{l}\text { The health facility not } \\
\text { too crowded }\end{array}$ & $19(8.7)$ & which is new concep & & \\
\hline & $\begin{array}{l}\text { The health service } \\
\text { was effective }\end{array}$ & $66(30.1)$ & $\begin{array}{l}\text { Table } 3 \text { Willingness to jc } \\
\text { insurance, reasons for jo } \\
\text { scheme in Debub Bench }\end{array}$ & $\begin{array}{l}\text { community bas } \\
\text { ing and not willir } \\
\text { istrict, Southwest }\end{array}$ & $\begin{array}{l}\text { health } \\
\text { to join the } \\
\text { thiopia, } 2013\end{array}$ \\
\hline & Other (specify) & $12(5.5)$ & Description & & Frequency \\
\hline Reasons for not getting & No enough money & $9(75.0)$ & & & (percent) \\
\hline & Others (too far, self limiting) & $3(25.0)$ & Willingness to join communit) & oased health insuranc & cheme $(n=808)$ \\
\hline Coverage of the health & Self & $204(93.2)$ & Yes & & $729(77.8)$ \\
\hline & Others (free, community) & $15(6.8)$ & No & & $179(22.2)$ \\
\hline Satisfaction with health & Very dissatisfied & $23(10.5)$ & Reasons for joining the sche & $=629)$ & \\
\hline & Dissatisfied & $61(27.9)$ & It provides free access to meo & al care & $475(75.5)$ \\
\hline & Neutral & $8(3.7)$ & To help others & & $29(4.6)$ \\
\hline & Satisfied & $111(50.7)$ & For security and peace of min & in times of ill-health & $79(12.6)$ \\
\hline & Very satisfied & $16(7.3)$ & Facing health problem freque & & $45(7.2)$ \\
\hline Perceived quality of the & Very low & $20(9.1)$ & Other (specify) & & $1(0.2)$ \\
\hline $\begin{array}{l}\text { health care service in the } \\
\text { district }(n=219)\end{array}$ & Low & $76(34.7)$ & Reasons for not joining the sc & eme $(n=179)$ & \\
\hline & Neutral & $24(11.0)$ & I do not have enough money & o pay & $44(24.6)$ \\
\hline & High & $87(39.7)$ & Do not need health insurance & & $59(33.0)$ \\
\hline & Very high & $12(5.5)$ & Out-of pocket charge is bette & & $17(9.5)$ \\
\hline Concern of the household & Very difficult & $77(35.2)$ & Lack of trust in government $p$ & grammes & $8(4.5)$ \\
\hline $\begin{array}{l}\text { for covering health care } \\
\text { costs }(n=219)\end{array}$ & Difficult & $110(50.2)$ & Lack of functional HF in my vi & & $24(13.4)$ \\
\hline & Not difficult & $32(14.6)$ & $\mathrm{H} /$ insurance is a confusing sch & & $14(7.8)$ \\
\hline & Drew from the savings & $38(20.3)$ & Others & & $13(7.3)$ \\
\hline
\end{tabular}

Table 2 Health and health related situations in Debub Bench District, Southwest Ethiopia, 2013 (Continued)

associated with WTJ. The probability of joining the scheme decreases by $1.6 \%$ as the time taken to reach the HFs increases by one minute. (95\% CI of AOR: .973,

\section{Discussion}

After presenting the scenario of community based health surance scheme, the respondents were asked whether . 
Table 4 Factors which are associated with willingness to join community based health insurances in Debub Bench, 2013

\begin{tabular}{|c|c|c|c|c|c|c|}
\hline \multirow[t]{2}{*}{ Variables } & \multirow[t]{2}{*}{ Freq (\%) } & \multicolumn{2}{|l|}{ WTJ } & \multirow[t]{2}{*}{ P-value } & \multirow[t]{2}{*}{ Crude OR } & \multirow[t]{2}{*}{ Adjusted OR $[95 \% \mathrm{Cl}]$} \\
\hline & & Yes (\%) & No (\%) & & & \\
\hline \multicolumn{7}{|l|}{ Demographic variables } \\
\hline Age & & $629(78)$ & $179(22)$ & .000 & 1.035 & $.943[.914, .974]$ \\
\hline Relationship & $808(100)$ & $629(78)$ & $179(22)$ & .007 & & \\
\hline Head* & $654(80.9)$ & $519(79)$ & $135(21)$ & & & \\
\hline Spouse & $132(16.3)$ & $97(73)$ & $35(27)$ & .042 & .721 & $.410[.174, .967]$ \\
\hline Others & $22(2.7)$ & $13(59)$ & $9(41)$ & .015 & .376 & $18.523[1.762,194.6]$ \\
\hline Religion† & $808(100)$ & $629(78)$ & $179(22)$ & .869 & & \\
\hline Protestant* & $550(68.1)$ & $431(78)$ & $119(22)$ & & & \\
\hline Orthodox & $199(24.6)$ & $160(80)$ & $39(20)$ & .936 & 1.133 & $.965[.410,2.275]$ \\
\hline Muslim & $41(5.1)$ & $24(58)$ & $17(42)$ & .957 & .390 & $1.042[.233,4.650]$ \\
\hline Others & $18(2.2)$ & $14(78)$ & $4(22)$ & .406 & .996 & $2.056[.375,11.262]$ \\
\hline Marital status & $808(100)$ & $629(78)$ & $179(22)$ & .019 & & \\
\hline Monogamous* & $573(70.9)$ & $458(80)$ & $115(20)$ & & & \\
\hline Polygamous & $101(12.5)$ & $84(83)$ & $17(17)$ & .061 & 1.241 & $.409[.160,1.043]$ \\
\hline Single & $55(6.8)$ & $25(45)$ & $30(55)$ & .002 & .209 & $.123[.032, .474]$ \\
\hline Widowers & $24(3.0)$ & $19(79)$ & $5(21)$ & .996 & .954 & $.996[.171,5.814]$ \\
\hline Divorced & $55(6.8)$ & $43(78)$ & $12(22)$ & .929 & .900 & $.950[.304,2.971]$ \\
\hline Occupations & $808(100)$ & $629(78)$ & $179(22)$ & .000 & & \\
\hline Farmers* & $615(76.1)$ & $501(81)$ & $114(19)$ & & & \\
\hline Housewives & $113(14.0)$ & $87(77)$ & $26(23)$ & .000 & .761 & $11.917[4.017,35.357]$ \\
\hline Merchants & $36(4.5)$ & $19(53)$ & $17(47)$ & .769 & .254 & $.821[.221,3.046]$ \\
\hline Students & $30(3.7)$ & $14(47)$ & $16(53)$ & .443 & .199 & $.521[.098,2.760]$ \\
\hline Others & $14(1.7)$ & $8(57)$ & $6(43)$ & .025 & .303 & $.088[.011, .738]$ \\
\hline Ethnicity & $808(100)$ & $629(78)$ & $179(22)$ & .000 & & \\
\hline Bench* & $519(64.2)$ & $404(78)$ & $115(22)$ & & & \\
\hline Amhara & $116(14.4)$ & $88(76)$ & $28(24)$ & .341 & .895 & $1.557[.626,3.875]$ \\
\hline Kaffa & $64(8.0)$ & $41(64)$ & $23(36)$ & .000 & .507 & $.184[.072, .468]$ \\
\hline Others & $109(13.5)$ & $96(88)$ & $13(12)$ & .004 & 2.102 & $5.306[1.682,16.733]$ \\
\hline Total family size & & & & .000 & & $1.691[1.363,2.099]$ \\
\hline \multicolumn{7}{|l|}{ Socioeconomic variables } \\
\hline Educational-status & $808(100)$ & $629(78)$ & $179(22)$ & .001 & & \\
\hline No education* & $388(48.0)$ & $316(81)$ & $72(19)$ & & & \\
\hline Read \& write only & $221(27.3)$ & $176(80)$ & $45(20)$ & .045 & .891 & $2.134[1.017,4.479]$ \\
\hline Grade 1-8 & $178(22.0)$ & $124(70)$ & $54(30)$ & .007 & .523 & $.321[.140, .738]$ \\
\hline Sec and above & $21(2.6)$ & $13(62)$ & $8(38)$ & .864 & .370 & $1.205[.143,10.161]$ \\
\hline Wealth quintile & $808(100)$ & $629(78)$ & $179(22)$ & .002 & & \\
\hline Low wealth quintile & $70(8.7)$ & $48(69)$ & $22(31)$ & .451 & .778 & $1.559[.492,4.938]$ \\
\hline Second wealth quintile* & $255(31.6)$ & $188(74)$ & $67(26)$ & & & \\
\hline Middle wealth quintile & $164(20.3)$ & $124(76)$ & $40(24)$ & .082 & 1.105 & $.481[.211,1.097]$ \\
\hline Fourth wealth quintile & $125(15.5)$ & $94(75)$ & $31(25)$ & .375 & 1.081 & $.672[.279,1.618]$ \\
\hline Highest wealth quintile & $194(24.0)$ & $175(90)$ & $19(10)$ & .003 & 3.282 & $4.203[1.616,10.931]$ \\
\hline Annual income & $808(100)$ & $629(78)$ & $179(22)$ & .003 & & \\
\hline Less than 1100 birr & $198(24.5)$ & $133(67)$ & $65(33)$ & .008 & .470 & $.475[.274, .823]$ \\
\hline 1100-4300 birr* & 409 (50.6) & $326(80)$ & $83(20)$ & & & \\
\hline
\end{tabular}


Table 4 Factors which are associated with willingness to join community based health insurances in Debub Bench, 2013 (Continued)

\begin{tabular}{|c|c|c|c|c|c|c|}
\hline More than 4300 birr & $201(24.9)$ & $170(85)$ & $31(15)$ & .180 & 1.768 & $1.500[.830,2.712]$ \\
\hline \multicolumn{7}{|c|}{ Participation in risk sharing organizations } \\
\hline No. of risky to become ill† & & & & .887 & 1.322 & $.980[.780,1.300]$ \\
\hline Iddir participation & $808(100)$ & $629(78)$ & $179(22)$ & & & \\
\hline Yes* $^{*}$ & $747(92.5)$ & $603(81)$ & $144(19)$ & & & \\
\hline No & $61(7.5)$ & $26(43)$ & $35(57)$ & .139 & & $.427[.138,1.320]$ \\
\hline \multicolumn{7}{|l|}{ Social capital } \\
\hline Indiv level hor trust & $808(100)$ & $629(78)$ & $179(22)$ & .000 & & \\
\hline Low & $233(28.8)$ & $144(62)$ & $89(38)$ & .000 & .339 & $.064[.025, .165]$ \\
\hline Middle* & $456(56.4)$ & $377(83)$ & $79(17)$ & & & \\
\hline High & $119(14.7)$ & $108(91)$ & $11(9)$ & .238 & 2.057 & $2.284[.580,9.000]$ \\
\hline Indiv level reciprocity & $808(100)$ & $629(78)$ & $179(22)$ & .050 & & \\
\hline Low & $222(27.5)$ & $136(61)$ & $86(39)$ & .952 & .341 & $.975[.435,2.187]$ \\
\hline Middle* & $451(55.8)$ & $371(82)$ & $80(18)$ & & & \\
\hline High & $135(16.7)$ & $122(90)$ & $13(10)$ & .015 & 2.024 & $4.959[1.362,18.052]$ \\
\hline Commun level hor trust & $808(100)$ & $629(78)$ & $179(22)$ & & & \\
\hline High & $158(19.6)$ & $146(92)$ & $12(8)$ & .000 & 4.207 & $25.233[6.355,100.195]$ \\
\hline Low $^{*}$ & $650(80.4)$ & $483(74)$ & $167(26)$ & & & \\
\hline \multicolumn{7}{|c|}{ Health and health related variables } \\
\hline Health status of the $\mathrm{HH}$ & $808(100)$ & $629(78)$ & $179(22)$ & .000 & . & \\
\hline Very poor ${ }^{a}$ & $50(6.2)$ & $48(96)$ & $2(4)$ & .996 & 4.546 & \\
\hline Poor & $166(20.5)$ & $145(87)$ & $21(13)$ & .456 & 1.308 & $1.391[.584,3.315]$ \\
\hline Medium* & $270(33.4)$ & $227(84)$ & $43(16)$ & & & \\
\hline High & $224(27.8)$ & $159(71)$ & $65(29)$ & .012 & .463 & $.381[.179, .811]$ \\
\hline Very high & $98(12.1)$ & $50(51)$ & $48(49)$ & .000 & .197 & $.165[.068, .402]$ \\
\hline Member with chronic illnesst & $808(100)$ & $629(78)$ & $179(22)$ & & & \\
\hline Yes & $61(7.5)$ & $57(93)$ & $4(7)$ & .476 & 4.360 & $1.563[.458,5.337]$ \\
\hline $\mathrm{No}^{*}$ & $747(92.5)$ & $572(77)$ & $175(23)$ & & & \\
\hline Illness in prev 3 monthst & $808(100)$ & $629(78)$ & $179(22)$ & & & \\
\hline $\mathrm{No}^{*}$ & $558(69.0)$ & $404(72)$ & $154(28)$ & & & \\
\hline Yes & $250(31.0)$ & $225(90)$ & $25(10)$ & .817 & 3.431 & $1.182[.287,4.869]$ \\
\hline Seeking medical treatment $†$ & $808(100)$ & $629(78)$ & $179(22)$ & & & \\
\hline Yes* $^{*}$ & $231(28.6)$ & $212(92)$ & $19(8)$ & & & \\
\hline No & $577(71.4)$ & $417(72)$ & $160(28)$ & .231 & 0.194 & $6.338[.308,130.434]$ \\
\hline Borrow for treatment & $808(100)$ & $629(78)$ & $179(22)$ & & & \\
\hline $\mathrm{No}^{*}$ & $530(65.6)$ & $381(72)$ & $149(28)$ & & & \\
\hline Yes & $278(34.4)$ & $248(89)$ & $30(11)$ & .004 & 3.233 & $2.836[1.403,5.730]$ \\
\hline Time to HF (in minutes) & $808(100)$ & $629(78)$ & $179(22)$ & .001 & .991 & $.983[.973, .992]$ \\
\hline Constant & & & & .340 & & 2.355 \\
\hline
\end{tabular}

Note: *reference categories with highest frequency tvariables which were significant in bivariate analysis but removed when the confounders are controlled in the multivariate logistic regression.

Wildly improbable odds ratio. 
Among 808 participants 629 (77.85\%) responded that they would enroll in the scheme. Depending on the premium set, the actual enrollment could be lower. For example, if the premium is set to be 162.61 ETB (8.9 US\$), only $50 \%$ of the households who are WTJ will enrol in the scheme. This translates the WTJ to be $38 \%$. There are also other factors which may lower the actual WTJ [21].

But, this initial figure is greater than findings from Edo state of Nigeria (60\%) [22]. The discrepancy may be attributed to the scenario employed in this study which was not used in the previous study. Various studies indicate that presenting scenarios about hypothetical markets such as health insurance schemes provides relatively accurate estimates. The difference may also be because of differences in the study areas. Obviously, people's utilities in most aspects differ in different geographic regions.

In the current study, among the ill 231 (92.4\%) had sought treatment for the illnesses they experienced, and 219 (94.8\%) got treatment. This situation is not concurrence with the low access to health in Ethiopia [2]. This indicates that the health seeking behavior of the people in the current study area is better than the broader national instance.

The potential WTJ in the current study area also exceeds that in Ecuador, which is 69\% [13]. This may be due to differences in study areas and demographic situations of the source population. The population in El Páramo Region of Ecuador, where the previous study was conducted, lacks official governance and the estimate number of the people is smaller than those in the current study. This situation led to small number of study participants which possibly yielded less precise estimate of WTJ in the El Páramo than the current findings.

The current finding is less than that found in 2004 in Ethiopia, in which the probability of WTJ the scheme was $94.7 \%$ [23]. The reason may be attributed to differences in the study areas and time of study. The current finding is almost similar to that conducted in Jimma town in 2009, in which the probability to join iddirbased health insurances were 76.5\% [16].

The number of total family size, housewives (in comparison to farmers), participation in iddirs, amount contributed to iddirs monthly, individual social capital and community level horizontal trust had positive associations with the probability of WTJ the CBHIS. These findings are similar with those found in South Africa [24], Lao PDR [25], Nigeria [22] and rural areas of China [26,27].

One interesting finding in this study is that age of the respondent is negatively associated with WTJ of the households. This finding is inconcurrent with other findings [28-33]. The potential reason for such variation is pertinent to the benefit package of the proposed health insurance scheme in Ethiopia. Unlike health insurance schemes in many countries, the Ethiopian communitybased health insurance scheme benefit package covers only the members of the households whose age is less than 18 years. As the age of the respondent in this study (mainly the head of the household) increases the probability of having family members who are eligible for the benefit package of the scheme is lower than the younger counterpart. Consequently the utility of joining the community-based health insurance scheme decreases. Such decision is in line with economic theories.

Few health related variables, such as seeking treatment during illnesses intrude, borrowing money for covering healthcare costs, which had no associations with probability of enrolling in iddir based health insurances in Jimma [16], had positive and significant associations with the outcome variable in the current study area. This discrepancy may be attributed to the differences in the study areas.

\section{Conclusion}

In Debub Bench District If CBHIS commences about $78 \%$ of the households would enroll in the scheme. In the scheme the farmers, the married households, the younger, Bench ethnic groups and illiterate are more likely to enroll the schemes. The frequency of these population groups in the district are shown to be the majority. Consequently, acceptance of the scheme can be considered high. Therefore, initiating the scheme will be beneficial in the district.

\section{Additional file}

Additional file 1: The questionnaire and community-based scenario used in the study.

\section{Abbreviations}

AOR: Adjusted odds ratio; CBHI: Community-based health insurance; CBHIS: Community-based health insurance scheme; $\mathrm{CHI}$ : Community health insurance; ETB: Ethiopian Birr; IBHIS: Iddir-based health insurance scheme; SHI: Social health insurance; SNNPR: Southern Nations, Nationalities and People's Region; WTJ: Willingness to join; WTP: Willingness to pay.

\section{Competing interests}

We declare that we have no any competing interests.

\section{Authors' contributions}

$M L$ was the principal investigator and wrote the paper. SO and BM made substantial contributions to the analysis and interpretation of the data. They also reviewed the first and second drafts. All authors read and approved the final manuscript.

\section{Acknowledgements}

We are grateful to acknowledge Jimma University College of Public Health and Medical Sciences for providing financial assistance for the study. We also like to acknowledge data collectors, schools in the selected kebeles, administration of Debub Bench District, Health and Education Office of the District and administrations of the selected kebeles. Finally, we gratefully thank the study participants. 


\section{Author details}

${ }^{1}$ Aman College of Health Sciences, Southern Nations, Nationalities and People's Regional Health Bureau, P.O. Box 240, Mizan-Aman, Ethiopia. ${ }^{2}$ Department of Health Services Management, Jimma University, Jimma, P.O. Box 371, Ethiopia. ${ }^{3}$ Department of Monitoring and Evaluation, Jimma University, Jimma, P.O. Box 371, Ethiopia.

Received: 24 December 2013 Accepted: 23 May 2014

Published: 11 June 2014

\section{References}

1. United Nations Development Programme (UNDP): Human Development Report 2011: Sustainability and Equity: A Better Future for All. United Nations Development Programme. New York City, USA: United Nations Development Programme (UNDP); 2011.

2. Federal Democratic Republic of Ethiopia Ministry of Health: Health and Health Related Indicators of 2011. Addis Ababa, Ethioiapia: Federal Democratic Republic of Ethiopia Ministry of Healt; 2011.

3. Federal Democratic Republic of Ethiopia Ministry of Health, Health Care Financing Team, Policy, Planning and Finance General Directorat, USAID Health Sector Financing Reform Project: Ethiopia's Fourth National Health Accounts, 2007/08; Federal Democratic Republic of Ethiopia Ministry of Health, USAID Health Sector Financing Reform Project. 2010.

4. Federal Democratic Republic of Ethiopia Ministry of Health: Health Sector Development Programme N Annual Performance Report EFY 2003. Addis Ababa, Ethiopia: Ministry of Health Ethiopia; 2011.

5. WHO: WORLD HEALTH STATISTICS 2011. (c) World Health Organization 2011 who geneva, 2011. Geneva: WHO; 2011.

6. Inka B, Bekele T: Poor Households' Experiences and Perception of User Fees for Health care: a mixed-method study from Ethiopia; A Working Paper 59. Young Lives. 2010.

7. WHO: The world health report: health systems financing: the path to universal coverage. [Internet]. Genev: 2010. Available from: http://www.who.int/whr/ 2010/en/index.html.

8. Federal Democratic Republic of Ethiopia Ministry of Health: Health Sector Development Program IV 2010/11 -2014/15. Federal Democratic Republic of Ethiopia Ministry of Health. 2010

9. USAID: Ethiopia Health Sector Financing Reform Midterm Project Evaluation. Addis Ababa, Ethiopia: USAID and Federal Ministry of Health Ethiopia; 2011

10. Dror DM, Preker AS: Social reinsurance : a new approach to sustainable community health financing. The International Bank for Reconstruction and Development/The World Bank and the International Labour Organisation. Geneva: THE WORLD BANK Washington, DC INTERNATIONAL LABOUR OFFICE; 2002.

11. Carrin G, Waelkens M-P, Criel B: Community-based health insurance in developing countries: a study of its contribution to the performance of health financing systems. Tropical Med Int Health 2005, 10(8):799-811.

12. Federal Ministry of Healt Ethiopiah: Planning and Programming Department. Addis Ababa: Health Insurance Strategy; 2008.

13. Eckhardt M, Forsberg BC, Wolf D, Crespo-Burgos A: Feasibility of community-based health insurance in rural tropical Ecuador. Rev Panam Salud Publica 2011, 29(3):177-184.

14. D. Arkin-Tenkorang: Health insurance for the informal sector in Africa: Design features, risk protection and resource mobilization. World Bank's Human Development Network Discussion Paper; 2001:1-47.

15. International Labour Organisation: Extending Social Protection in Health Through Community Based Health Organisations. Evidence and Challenges. Universitas Programme, STEP unit. Geneva: Social Security Policy and Development Branch; 2002.

16. Ololo S, Jirra C, Hailemichael Y, Girma B: Indigenous Community Insurance (IDDIRS) as an alternative health care financing in Jimma city, Southwest Ethiopia. Ethiop J Health Sci 2009, 19(1):53-60.

17. Dercon S, Bold T, De Weerdt J, Dercon S, Bold T, Pankhurst A: Extending insurance? Funeral Associations in Ethiopia and Tanzania. OECD Development Centre. 2004.

18. Abay A, Von Joachim B: Innovations in Health Care Financing: New Evidence on the Prospect of Community Health Insurance Schemes in the Rural Areas of Ethiopia. Int J Health Care Finance Econ 2005, 5:241-253.

19. Federal Democratic Republic of Ethiopia Population Census Commission: Summary and Statistical Report of the 2007 Population and Housing Census Results. Addis Ababa: Central Statistical Authority; 2008.
20. Dong H, Kouyate B, Sauerborn R, Cairns J, Mugisha F: Willingness-to-pay for community-based insurance in Burkina Faso. Health Econ 2003, 12:849-862.

21. Durairaj V: Streamlining private out-of-pocket spending through Medisave: rural women's willingness and ability to pay for Medisave in Karnataka, India. The private sector in health care delivery - potentials and challenges. Stokholm: IHCAR, Department of Public Health Sci-ences, Karolinska Institutet; 2006:42-43.

22. Oriakhi HO, Onemolease EA, Amla Raj: Determinants of Rural Household's Willingness to Participate in Community Based Health Insurance Scheme in Edo State, Nigeria. Ethno Med 2012, 6(2):95-102.

23. Asfaw A, Braun J: Can community health insurance schemes shield the poor against the downside health effects of economic reforms? The case of rural Ethiopia. Health Policy 2004, 70:97-108.

24. Joses M, Kirigia Luis G, Sambo B, Nganda Germano M, Mwabu Rufaro C, Takondwa M: Determinants of health insurance ownership among South African women. BMC Health Serv Res 2005, 5:17.

25. The World Bank: Community Based Health Insurance in Lao P.D.R. Understanding Enrollment and Impacts. World Bank and London School of Hygiene and Tropical Medicine (LSHTM) World Health Organization (WHO). 2010.

26. Wang H, Yip W, Zhang L, Wang L: Community-based health insurance in poor rural China: the distribution of net benefits. Health Policy Plann 2005, 20(6):366.

27. Zhang L, Wang H, Wang L, Hsiao W: Social capital and farmer's willingness-to-join a newly established community-based health insurance in rural China. Health Policy 2006, 76(2):233-242.

28. Dror $M$, Radermacher $R$, Koren $R$ : Willingness to pay for health insurance among rural and poor persons: Filed evidence from seven micro health insurance units in India. Health Policy 2007, 82:12-27.

29. Ali A, Ken W, Ali Akbar T, Mojtaba R: Estimating rural households' willingness to pay for health insurance. Eur J Health Econom 2004, 5:209-215.

30. Curt L, Thanh NX, Nguyen TK C, Anders E, Lars L: People's willingness to pay for health insurance in rural Vietnam Published: Cost Effectiveness and Resource Allocation. BioMed Central Ltd [Internet] 2008, 6:16. Available from: http://www.resource-allocation.com/content/6/1/16 2008 Curt Lofgren, Nguyen X Thanh, Nguyen TK Chuc, Anders Emmelin and Lars Lindholm

31. Donfouet HPP, Essombè JRE, Mahieu PA, Malin E: Social Capital and Willingness-to-Pay for Community-Based Health Insurance in Rural Cameroon. Global J Health Sci 2011, 3(1):142.

32. Onwujekwe O, Onoka C, Uguru N, Tasie N: Socio-economic and geographic differences in acceptability of community-based health insurance. Public Health 2011, 125(11):806.

33. Babatunde OA, Akande TM, Salaudeen AG, Aderibigbe SA, Elegbede OE, Ayodele LM: Willingness to Pay for Community Health Insurance and its Determinants among Household Heads in Rural Communities in North-Central Nigeria. Int Rev Soc Sci Humanitie 2012, 2(2):133-142.

\section{doi:10.1186/1471-2458-14-591}

Cite this article as: Haile et al:: Willingness to join community-based health insurance among rural households of Debub Bench District, Bench Maji Zone, Southwest Ethiopia. BMC Public Health 2014 14:591.

\section{Submit your next manuscript to BioMed Central and take full advantage of:}

- Convenient online submission

- Thorough peer review

- No space constraints or color figure charges

- Immediate publication on acceptance

- Inclusion in PubMed, CAS, Scopus and Google Scholar

- Research which is freely available for redistribution 